\title{
18. IN SITU PERMEABILITY TESTS AT SITE 892: CHARACTERISTICS OF A HYDROGEOLOGICALLY ACTIVE FAULT ZONE ON THE OREGON ACCRETIONARY PRISM ${ }^{1}$
}

\author{
Elizabeth J. Screaton, ${ }^{2}$ Bobb Carson, ${ }^{2}$ and Gerard P. Lennon ${ }^{3}$
}

\begin{abstract}
In situ transmissivity of a hydrogeologically active fault zone within the Oregon accretionary prism was tested during Ocean Drilling Program (ODP) Leg 146. This experiment used an inflatable drill-string packer to conduct pressurized slug tests and constant-rate injection tests. Pressure responses during testing indicate dilation of fractures as a result of fluid injection. Consequently, test data allow examination of the transmissivity of an open fracture network. Analysis of pressurized slug-test data yields an average transmissivity of $1.0 \times 10^{-5} \mathrm{~m}^{2} \mathrm{~s}^{-1}$, while recovery data from the constant-rate injection tests indicate transmissivities ranging from 4.7 to $9.2 \times 10^{-5} \mathrm{~m}^{2} \mathrm{~s}^{-1}$. Test data indicate background borehole fluid pressure was 0.25 to 0.30 MPa greater than hydrostatic (approximately one-half lithostatic excess pressure) and indicate that fractures within the fault zone remain open at pressures approximately 0.315 to $0.325 \mathrm{MPa}$ above hydrostatic.
\end{abstract}

\section{INTRODUCTION}

Drilling at Ocean Drilling Program (ODP) Site 892 provided an opportunity to investigate the role of a thrust fault on the Oregon accretionary prism as a fluid conduit. Focused fluid flow along this fault zone has been inferred from submersible observations of vent sites concentrated along the fault trace (Moore, 1991) and from observed disruption of a prominent bottom-simulating reflector (BSR), presumably by the upward migration of warm fluids (Shipboard Scientific Party, 1994). Presently, knowledge of fault-zone permeability within accretionary prisms is limited to laboratory studies on sediment samples, which are not necessarily representative of in situ permeabilities, because the sample may not be large enough to be representative of fractured material and because test conditions may not duplicate in situ pressures. In this investigation, downhole packer tests were conducted during Leg 146 to determine the hydrogeologic properties of the fault zone. Results of these packer tests provide the first field determinations of transmissivity and pore pressure within a modern accretionary prism fault zone. In addition, the packer test results provide insight on the state of stress within the second ridge of the accretionary prism.

\section{BACKGROUND}

ODP Site 892 lies 674 meters below sea level on the western flank of the second ridge of the accretionary prism. The site was positioned to intersect a hydrogeologically active, landward-dipping fault that was seismically imaged 107 to 113 meters below seafloor (mbsf; Shipboard Scientific Party, 1994). The surface trace of the fault, located approximately $350 \mathrm{~m}$ west of the site, is marked by an accumulation of diagenetic carbonate (bioherm). At the bioherm, Linke et al. (1994) recorded a fluid discharge rate of $2.0 \mathrm{~m}^{3} \mathrm{~m}^{-1} \mathrm{~s}^{-1}$, and venting fluids support clam communities and bacterial mats (Moore, 1991).

Carson, B., Westbrook, G.K., Musgrave, R.J., and Suess, E. (Eds.), 1995. Proc. ODP, Sci. Results, 146 (Pt. 1): College Station, TX (Ocean Drilling Program).

${ }^{2}$ Department of Earth and Environmental Sciences, Lehigh University, Bethlehem, PA 18015. U.S.A.

'Department of Civil and Environmental Engineering, Lehigh University, Bethlehem, PA 18015, U.S.A.
The packer tests were conducted in Hole $892 \mathrm{~B}$ and tested the interval from $93.6 \mathrm{mbsf}$ to the bottom of the hole (178.5 mbsf; Figure 1). Core samples from Hole $892 \mathrm{~A}$, located approximately $200 \mathrm{~m}$ south-southwest of $892 \mathrm{~B}$, provide information concerning downhole lithology, the nature of the fault zone, and the location of active fluid flow zones. Lithology is relatively uniform downhole, and consists of terrigenous clayey silt with scattered silty clay and very fine sand (Shipboard Scientific Party, 1994). Intense shear-zone fabrics were observed in cores from 106.5 to $175 \mathrm{mbsf}$, and the interval from 106.5 to 116 mbsf contained open scaly fractures (Shipboard Scientific Party, 1994). A biostratigraphic inversion observed at depths of 106 to 117 mbsf confirms the position of the fault zone (Shipboard Scientific Party, 1994). Active fluid flow is evidenced at $107 \mathrm{mbsf}$ in Hole $892 \mathrm{~A}$ by the occurrence of thermogenic hydrocarbons, that indicate transport from depth (Shipboard Scientific Party, 1994).

Following the packer tests, a borehole seal (CORK; Davis et al., 1992) was deployed in Hole $892 \mathrm{~B}$ to provide long-term observation across the faulted section. The CORK contains a datalogger which records information from an in-hole pressure gauge and 10 downhole thermistors (Davis et al., this volume). The CORK also contains a sampling port through which a second set of hydrogeologic tests were conducted approximately 10 months after ODP Leg 146.

\section{TEST PROCEDURES}

Prior to the packer test, a re-entry cone and 16-in $(0.41 \mathrm{~m})$ casing were jetted in to a depth of 21 mbsf (Figure 1). A 143/4-in $(0.37 \mathrm{~m})$ hole was then drilled to $105 \mathrm{mbsf}$, and $72 \mathrm{~m}$ of $113 / 4$-in $(0.30 \mathrm{~m})$ casing were hung below the 16 inch $(0.41 \mathrm{~m})$ casing and cemented to a depth of 93.6 mbsf (the depth of the 113/4-in casing). After $36 \mathrm{hr}$, the cement plug and shoe were drilled out, and $73.5 \mathrm{~m}$ of 9 -in $(0.25 \mathrm{~m})$ hole were drilled to $178.5 \mathrm{mbsf}$. Ten $\mathrm{m}$ of unperforated 5 -in $(0.13 \mathrm{~m})$ pipe and $50 \mathrm{~m}$ of perforated ( $9.5 \%$ open area) pipe were hung from the $113 / 4$-in $(0.30 \mathrm{~m})$ casing. Total time that the borehole was open between the completion of drilling and cleaning operations and the beginning of the packer tests was approximately 12 hours. Prior to the start of the packer tests, a seafloor video camera showed fluid flowing from the borehole.

The permeability of the lower section of Hole 892B was measured using a reseatable drill-string packer (Becker, 1988). The packer was 


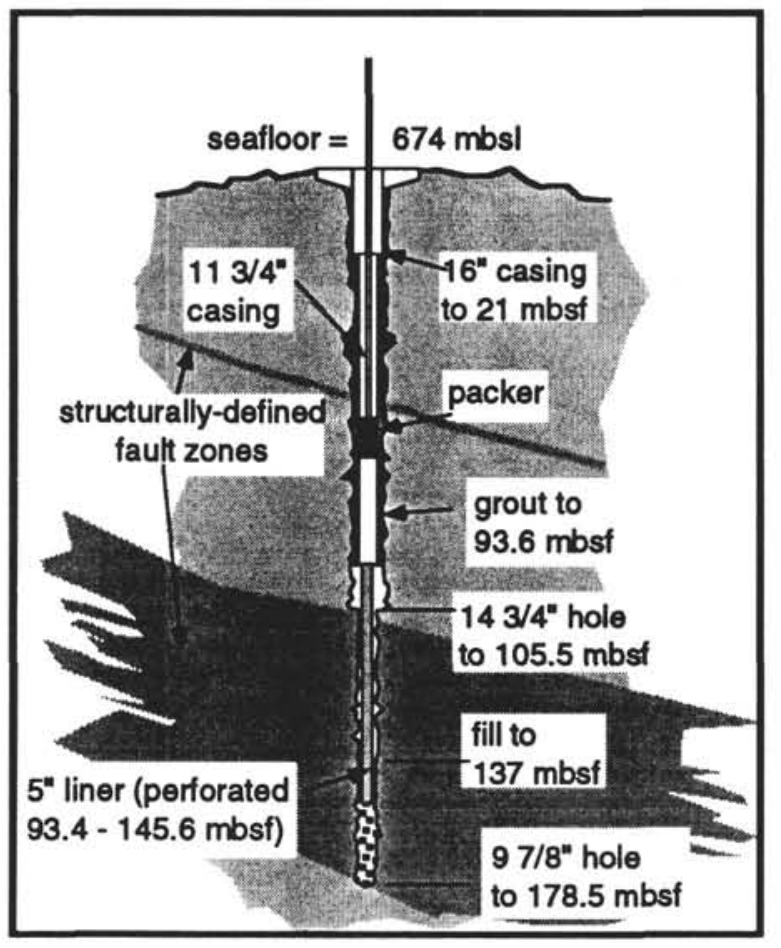

Figure 1. Schematic of the casing and open hole during packer testing in Hole 892B. Designated hole size is that of the drill bit used; actual hole diameter will vary.

inflated in the $113 / 4$-in casing with two elements together as a double-seal packer to isolate the zone between the base of the cement (93.6 mbsf) and the bottom of the hole (178.5 mbsf). The packer is actuated by a "go-devil" that is dropped down the drill string and directs seawater pumped from the ship into the inflatable packer elements. Once the packer elements are fully inflated and grip the casing, the drill-string heave compensator is adjusted to transfer weight onto the inflated packer, closing the inflation-deflation port and opening the interval isolated by the packer to fluid pressure or flow applied by shipboard pumps.

Two pressure recorders, one mechanical Kuster K-3 recorder and one electronic ERPG-300 gauge, monitored downhole fluid pressures during the test. Because these data were not available until the recorders were retrieved at the end of the test, a pressure transducer at the rig floor provided real-time pressure information, as the entire drill-string volume was pressurized. Volumes and rates of fluid pumped into the isolated zone were monitored by counting pump strokes at the rig floor ( 1 stroke delivers approximately $18 \mathrm{~L}$ ).

Two kinds of experiments were conducted to determine the permeability of the isolated interval: pressurized slug tests and constant-rate injection tests. The pressurized slug tests (hereafter referred to simply as "slug tests") followed the methods of Bredehoeft and Papadopulos (1980) and consisted of applying a pressure pulse and monitoring the decay as fluid flowed from the borehole into the formation. In the constant-rate injection tests, borehole pressure was monitored as fluids were pumped into the formation at a constant rate andduring the subsequent pressure recovery. The methods used are similar to those described by Anderson and Zoback (1982), Hickman et al. (1984), Anderson et al. (1985), and Becker $(1989,1991)$ when conducting packer experiments in Holes 395A and 504B for the Deep Sea Drilling Project (DSDP) and ODP. In general, slug tests are most useful for low-permeability formations, but decay too quickly to be analyzed in high-permeability formations. During testing, slug tests are generally run first, and if the pressure pulses appear to decay rapidly (within several minutes), constant-rate injection tests are conducted.

The packer was inflated within the $113 / 4$-in casing to about 1500 psi (10.3 MPa), and four slug tests were conducted (Figure 2). The initial slug test occurred following packer inflation; although most of the packer inflation pressure was released to the upper borehole annulus, some was applied to the isolated portion of the borehole. The three subsequent pressure pulses were produced by the injection of approximately $140 \mathrm{~L}$ in $22 \mathrm{~s}, 200 \mathrm{~L}$ in $22 \mathrm{~s}$, and $250 \mathrm{~L}$ in $32 \mathrm{~s}$ (times are approximate because they are estimated from the downhole pressure record with pressure readings every $10.8 \mathrm{~s}$ ). Rapid decay of the pressure peaks $(<5 \mathrm{~min})$ on the uphole pressure recorder during the slug tests suggested high-permeability materials. Therefore, constant-rate injection tests were initiated. The first two tests were run at 11 and 20 strokes per minute (spm; approximately 3.3 and $6.0 \mathrm{Ls}^{-1}$, respectively). Uphole pressure measurements indicated pressure decreases following an initial peak value. These records deviate from ideal injection tests, in which pressure increases continuously with time, and represent either increased permeability within the tested section induced by the applied pressure or an incomplete seal of the packer during the injection tests. The video camera at the seafloor showed no evidence of fluid escape through or around the re-entry cone while the packer was seated, whereas fluid had been clearly flowing from the borehole prior to the inflation of the packer. Therefore, we concluded that the seal was intact, and a third injection test was conducted at $8 \mathrm{spm}\left(2.4 \mathrm{Ls}^{-1}\right)$, a lower pumping rate. Although no pressure decrease was observed during Injection Test 3 , pressure stabilized after approximately 100 seconds of injection, again suggesting opening of fractures.

\section{DATA ANALYSIS}

Because the fault zone at Site 892 consists of a network of scaly fractures (Shipboard Scientific Party, 1994) that are small relative to the thickness of the tested interval, we treated this fault zone as an

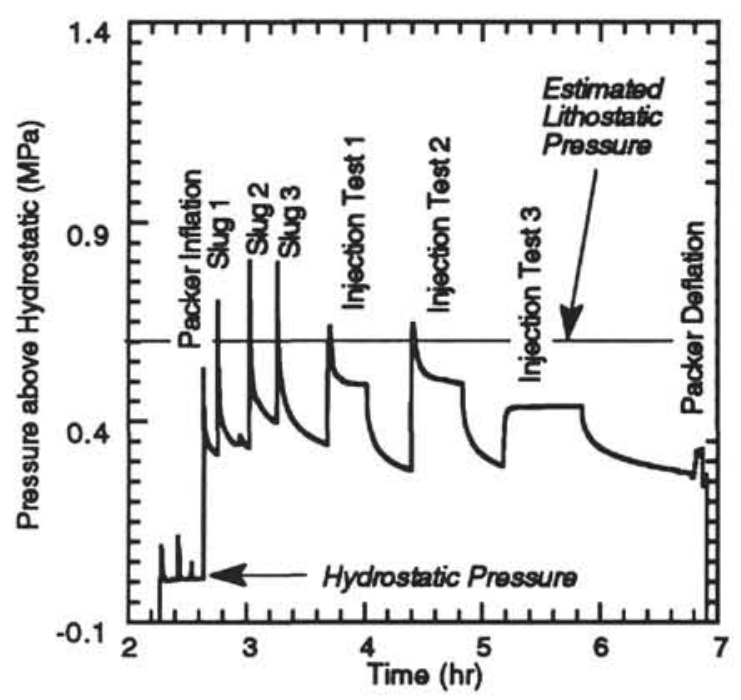

Figure 2. Downhole pressure record from the first set of tests expressed relative to hydrostatic pressure. Line represents estimated lithostatic pressure at $93.6 \mathrm{mbsf}$, assuming overlying sediments have a bulk density of 1.700 $\mathrm{Mg} / \mathrm{m}^{3}$. 
equivalent porous medium and applied traditional aquifer test methods to evaluate hydrogeologic properties from the packer test data.

\section{Slug Tests}

The decay of a pressure pulse is described by the equation (Cooper et al., 1967; Papadopulos et al., 1973; Bredehoeft and Papadopulos, 1980):

$$
P(t) / P_{0}=F(\alpha, \beta),
$$

where $P$ is pressure in excess of the initial undisturbed value, $P_{0}$ is the maximum pressure in excess of the initial undisturbed value, and $\alpha$ and $B$ are variables defined by:

$$
\begin{gathered}
\alpha=\pi r^{2} S / V C \rho g, \\
B=\pi T t / V C \rho g,
\end{gathered}
$$

where $S$ is storativity, $T$ is transmissivity, $t$ is time, $g$ is gravitational acceleration, $r$ is the radius of the hole in the tested interval, and $C$ and $\rho$ are the compressibility and density of the fluid in the total pressurized volume $(V)$, respectively (we omit the subscript ${ }_{\mathrm{w}}$ used by Bredehoeft and Papadopulos, 1980). The function $F(\alpha, \beta)$ is given by

$$
F(\alpha, \beta)=\left(8 \alpha / \pi^{2}\right) \int_{0}^{\infty} \mathrm{d} u \exp \left(-\beta u^{2} / \alpha\right) / u f(u, \alpha),
$$

where $f(u, \alpha)=\left[u J_{0}(u)-2 \alpha J_{l}(u)\right]^{2}+\left[u Y_{0}(u)-2 \alpha Y_{l}(u)\right]^{2}, u$ is the variable of integration, and $J_{0}, J_{l}, Y_{0}$, and $Y_{l}$ are Bessel functions of the first and second kind. Tables of the function $F(\alpha, \beta)$ against $\beta$ are given by Cooper et al. (1967) and Bredehoeft and Papadopulos (1980). These values are plotted to make a family of type-curves of $F(\alpha, \beta)$ as a function of $\log \beta$ for various $\alpha$ values. To analyze the test data, observed values of $P / P_{0}$ are plotted as a function of the logarithm of time and matched with a type curve by keeping the $B$ and $t$ axes coincident while moving the plots horizontally. The $\alpha, B$ and $t$ values from a match point are substituted into Equations 2 and 3 to determine the transmissivity and the storativity of the tested interval.

Bredehoeft and Papadopulos (1980) note that for large values of $\alpha$, the shapes of the type curves, $F(\alpha, \beta)$ against $\beta$, become increasingly similar and the horizontal shift between the type curves increases. Therefore, for values of $\alpha$ greater than 0.1 , it is necessary to match the data to type curves of $F(\alpha, \beta)$ against the product, $\alpha \beta$ (Bredehoeft and Papadopulos, 1980). Since $\alpha$ is not known prior to analysis, the method for $\alpha \leq 0.1$ is first applied. If $\alpha$ is found to be $<0.1$, data are matched to the product parameter $\alpha \beta$. Comparison of the data to this set of type curves allows determination as to whether the data are adequate to identify $\alpha$ (i.e., to select a particular type curve). If the data are not adequate to determine $\alpha$ (i.e., if the data can be matched by more than one type curve), only the product, TS, can be estimated.

The effective compressibility of the fluid in a shut-in hole is sometimes greater than that of the pure fluid because of (1) compliance of the drill-string and test equipment and (2) air (or gas) trapped in the system (Neuzil, 1982). The effective compressibility of the pressurized system was calculated using the definition the compressibility: $C=d V / V d P$, where $d V$ is the volume pumped downhole during each slug test, $V$ is the total pressurized volume (including the isolated zone, the drill-string, and the rig floor plumbing) and $d P$ is the pressure increase $\left(P_{0}\right.$ in Equation 1$)$. Calculated compressibilities (Table 1) were up to 2 orders of magnitude greater than that of pure seawater. Fracture dilation during injection of the pressure pulse may contribute to these high calculated fluid compressibilities by decreasing the magnitude of the pressure pulse, $d P$.

\section{Constant-rate Injection Tests}

In a constant-rate injection test, borehole pressures within the isolated zone are monitored as fluids are pumped into the formation at a constant rate $(Q)$. Change in hydraulic head, $\Delta h$, during shut-in following a constant-rate injection test can be approximated by

$$
T=(0.183 Q / \Delta h) \log \left(t / t^{\prime}\right),
$$

where $t$ is time since injection began, and $t^{\prime}$ is time since shut-in (Theis, 1935). In terms of pressure, this becomes

$$
T=(0.183 Q \rho g / \Delta P) \log \left(t / t^{\prime}\right)
$$

This approximation is considered to introduce negligible error at times such that

$$
r^{2} S / 4 T t<0.01
$$

The transmissivity of the tested zone is determined by plotting $\Delta P$ as a function of the logarithm of $t / t^{\prime}$. A straight line is then fit to late-time data (i.e., near the origin of the $t / t^{\prime}$ axis), and the slope of the line $\left(\Delta P / \log \left(t / t^{\prime}\right)\right.$ is substituted into Equation 6 to calculate transmissivity.

\section{Permeability Estimates}

Permeability $(k)$ is related to transmissivity by $k=T \mu / b \rho g$, where $\mu$ is viscosity and $b$ is the aquifer thickness. A temperature of $8^{\circ} \mathrm{C}$, intermediate between the temperature of injected fluid $\left(6^{\circ} \mathrm{C}\right)$, and the estimated formation temperature $\left(10.8^{\circ}\right.$ to $\left.14.6^{\circ} \mathrm{C}\right)$ was used to estimate a viscosity of $1.5 \times 10^{-3} \mathrm{~Pa}$ (Kennish, 1989).

The maximum thickness of the active flow zone is constrained by information from the 10-month data record following CORK deployment at Hole 892B. The temperature data from a thermistor at 100 mbsf showed a $4^{\circ} \mathrm{C}$ rise, (Davis et al., this volume), indicating fluid flow at this depth. Thermistors located at 92 and $116 \mathrm{mbsf}$ did not show a temperature rise, constraining the thickness of the active flow zone to be less than $24 \mathrm{~m}$. A minimum thickness of the active flow zone is more difficult to constrain, and for purposes of estimating a reasonable upper value for the fault-zone permeability, we assume a 1 -m-thick fault zone. These estimated maximum and minimum thicknesses provide a range of estimated fault-zone permeabilities.

\section{RESULTS Slug Tests}

The initial pore pressure during the slug tests was estimated by finding the value for which $P / P_{0}$ vs. $\log$ time best fit the type curve. During this analysis, data from each slug test were corrected for the incomplete decay of previous tests by subtracting the extrapolated pressure decay curves. Therefore, this initial pressure is assumed to represent the background pore pressure in the vicinity of the borehole. The slug test data are best fit by assuming a background pressure $0.30 \mathrm{MPa}$ above hydrostatic (Figure 3). Although the quality of the curve fit is sensitive to the assumed background pressure, the computed transmissivities are not strongly dependent on this parameter (Table 1). 
Table 1. Calculated compressibilities, transmissivities, and intrinsic permeabilities.

\begin{tabular}{|c|c|c|c|c|c|c|}
\hline Test & $\begin{array}{c}\text { Compressibility } \\
\left(10^{-8} \mathrm{~Pa}^{-1}\right)\end{array}$ & $\begin{array}{c}\text { Background } \\
\text { pressure (MPa) }\end{array}$ & $\alpha$ & $\begin{array}{c}\text { Transmissivity } \\
\left(10^{-6} \mathrm{~m}^{2} \mathrm{~s}^{-1}\right)\end{array}$ & $\begin{array}{c}\text { Lower estimate } \\
\text { permeability } \\
\left(10^{-14} \mathrm{~m}^{2}\right)\end{array}$ & $\begin{array}{l}\text { Upper estimate } \\
\text { permeability } \\
\left(10^{-14} \mathrm{~m}^{2}\right)\end{array}$ \\
\hline Packer inflation & $\begin{array}{l}\mathrm{NC}^{*} \\
\mathrm{NC} \\
\mathrm{NC} \\
\mathrm{NC}\end{array}$ & $\begin{array}{l}2.5 \\
0.30 \\
\mathbf{0 . 3 0} \\
0.30\end{array}$ & $\begin{array}{l}0.3 \\
0.3 \\
1.0 \\
2.0\end{array}$ & $\begin{array}{c}7.7 \\
15 \\
8.1 \\
5.1\end{array}$ & $\begin{array}{l}4.8 \\
9.3 \\
\mathbf{5 . 0} \\
3.1\end{array}$ & $\begin{array}{r}110 \\
220 \\
120 \\
75\end{array}$ \\
\hline Slug test 1 & $\begin{array}{l}2.5 \\
2.7 \\
2.7 \\
2.7\end{array}$ & $\begin{array}{l}0.25 \\
0.30 \\
\mathbf{0 . 3 0} \\
0.30\end{array}$ & $\begin{array}{l}0.1 \\
0.1 \\
\mathbf{0 . 3} \\
1.0\end{array}$ & $\begin{array}{c}18 \\
29 \\
12 \\
7.2\end{array}$ & $\begin{array}{c}11 \\
18 \\
7.4 \\
4.4\end{array}$ & $\begin{array}{l}270 \\
420 \\
180 \\
110\end{array}$ \\
\hline Slug test 2 & $\begin{array}{l}2.8 \\
3.0 \\
3.0 \\
3.0\end{array}$ & $\begin{array}{l}0.25 \\
0.30 \\
0.30 \\
0.30\end{array}$ & $\begin{array}{l}1.0 \\
0.3 \\
1.0 \\
2.0\end{array}$ & $\begin{array}{l}2.6 \\
7.5 \\
3.6 \\
3.6\end{array}$ & $\begin{array}{l}1.6 \\
4.6 \\
2.2 \\
2.2\end{array}$ & $\begin{array}{r}38 \\
110 \\
53 \\
53\end{array}$ \\
\hline Slug test 3 & $\begin{array}{l}3.9 \\
4.1 \\
4.1 \\
4.1\end{array}$ & $\begin{array}{l}0.25 \\
0.30 \\
\mathbf{0 . 3 0} \\
0.30\end{array}$ & $\begin{array}{l}1.0 \\
0.1 \\
0.3 \\
1.0\end{array}$ & $\begin{array}{l}3.7 \\
15 \\
10 \\
5.4\end{array}$ & $\begin{array}{l}2.3 \\
9.4 \\
6.3 \\
3.3\end{array}$ & $\begin{array}{r}54 \\
230 \\
150 \\
80\end{array}$ \\
\hline
\end{tabular}

Notes: $" \mathrm{NC}=$ Not calculated. Compressibility for the test following packer inflation could not be calculated; compressibility values from the subsequent test were used to calculate transmissivity for this test. ${ }^{*}$ Bold numbers are results for the best-fit type curve; other values given to show sensitivity to choice of background pressure and type curve.

Because the values of $\alpha$ were found to be greater than 0.1 , data were matched to type curves of $F(\alpha, \beta)$ against the product, $\alpha \beta$. A perturbation in the decay of Slug Test 2 (a small pressure rise) occurred after 4 minutes, making subsequent data unusable, and the usable data were not sufficient to unequivocally select a type curve. Therefore, results are not included in the average. Data from the other three slug tests were sufficient to identify a type curve $(\alpha)$ and solve for transmissivity (Table 1 ). The selected $\alpha$ values yield storativity values ranging from 0.007 to 0.025 , assuming a borehole radius of 0.23 $\mathrm{m}$. These values are higher than normally encountered in aquifer testing $(0.00005$ to 0.005 ; Freeze and Cherry, 1979), probably because this formation is higher porosity and more clay-rich than most aquifers. As seen in Equation 3, estimated storativity is inversely proportional to the square of the borehole radius. Consequently, inaccuracies in the assumed borehole radius will affect storativity results, although transmissivity results will not be affected. Additional error is caused by the uncertainty in type-curve selection (Bredehoeft and Papadopulos, 1980).

Estimated transmissivities for the Packer Inflation, Slug Test 1, and Slug Test 3 were $8.1 \times 10^{-6}, 1.2 \times 10^{-5}$, and $1.0 \times 10^{-5} \mathrm{~m}^{2} \mathrm{~s}^{-1}$, respectively. Sensitivity to chosen curves was tested by matching data to the next higher and lower type curves; computed transmissivities are shown in Table 1. Estimated bulk permeabilities for these tests assuming a fault-zone thickness of $24 \mathrm{~m}$, were $5.0 \times 10^{-14}, 7.4 \times 10^{-14}$ and $6.3 \times 10^{-14} \mathrm{~m}^{2}$, respectively, with a geometric mean of $6.1 \times 10^{-14}$ $\mathrm{m}^{2}$. If a fault-zone thickness of $1 \mathrm{~m}$ is assumed, the permeabilities were $1.2 \times 10^{-12}, 1.8 \times 10^{-12}$ and $1.5 \times 10^{-12} \mathrm{~m}^{2}$, respectively, with a geometric mean of $1.5 \times 10^{-12} \mathrm{~m}^{2}$.

\section{Constant-rate Injection Tests}

Analysis of the pressure records from the constant-rate injection tests yields information concerning the state of stress within the formation as well as estimates of open-fracture transmissivity. The pressure responses during injection (Figure 2) indicate that fractures remain open below lithostatic pressure. Injection Tests 1 and 2 were not sufficient in duration to determine an equilibrium pumping pres- sure (the sum of the pressure necessary to keep the fracture open, the viscous pressure loss during pumping, and the pressure necessary to propagate the fracture; Hickman and Zoback, 1983) but are clearly equilibrating well below lithostatic pressure. Pumping pressure during Injection Test 3 is approximately $0.44 \mathrm{MPa}$ above hydrostatic. At $93.6 \mathrm{mbsf}$ (the top of the tested interval), the estimated difference between lithostatic and hydrostatic pressure is $0.6 \mathrm{MPa}$, assuming an average bulk density of $1.700 \mathrm{Mg} / \mathrm{m}^{3}$ (from Site 892 physical properties and downhole logging results) and a fluid density of 1.035 $\mathrm{Mg} / \mathrm{m}^{3}$.

The instantaneous shut-in pressure (ISIP, the pressure at which the fractures close) and the formation pressure were estimated following the method described by Cornet and Valette (1984). Instantaneous shut-in pressure is estimated as $0.315 \mathrm{MPa}$ above hydrostatic for Injection Test 1 and $0.325 \mathrm{MPa}$ above hydrostatic for Injection Tests 2 and 3 (Figure 4). This value is well below lithostatic pressure, suggesting that the overburden is not the least principal stress. Formation pressure during the constant-rate injection tests was determined to be $0.25 \mathrm{MPa}$ above hydrostatic (Figure 4), lower than that observed during the slug tests. Although uncertainty exists in the estimation of background pressure, this value suggests the possibility that formation pressure in the vicinity of the borehole was dropping during packer testing. This trend is consistent with pressure decay recorded following CORK installation (Davis et al., this volume). An alternate explanation is that slug-test pressure pulses decayed to the fracture-closing pressure (approximately 0.315 to $0.325 \mathrm{MPa}$ above hydrostatic), rather than to the formation pressure.

Interpretation of the shut-in data by the Theis recovery method provides an approximation of fault-zone transmissivity with open fractures, although this method may not be strictly applicable because fractures may be closing during the recovery, decreasing transmissivity. To minimize this effect, only the data from pressures where fractures are inferred to be open (above 0.315 or $0.325 \mathrm{MPa}$, as appropriate) were used. Analysis of the data (Figure 5) yields transmissivity values for Injection Tests 1,2 , and 3 of 4.7, 9.2, and $5.4 \times 10^{-5} \mathrm{~m}^{2} \mathrm{~s}^{-1}$, respectively (Table 1 ). Substitution of these transmissivity values and an assumed storativity of 0.01 into Equation 7 


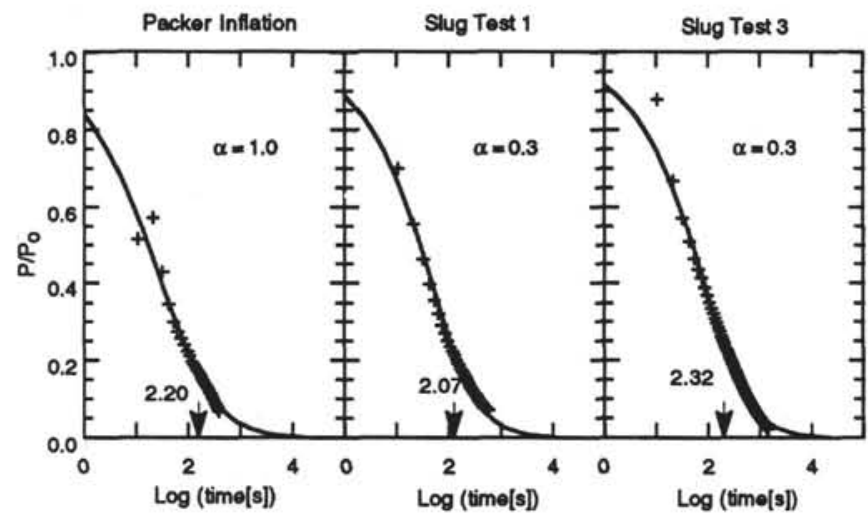

Figure 3. Plots of normalized excess pressures as a function of time for slug tests and selected type curves. Text indicates the logarithm of the amount that the type curve was shifted (i.e., the value of $t$ at which $\alpha \beta=1$ ).

indicates that the approximation inherent in Equation 6 introduces negligible error at times greater than $280 \mathrm{~s}, 140 \mathrm{~s}$, and $240 \mathrm{~s}$, for Injection Tests 1,2 , and 3 , respectively.

These transmissivity values correspond to permeabilities of 2.9 , 5.7 , and $3.3 \times 10^{-13} \mathrm{~m}^{2}$ for an assumed flow-zone thickness of $24 \mathrm{~m}$, and permeabilities of $7.0,14$, and $8.0 \times 10^{-12} \mathrm{~m}^{2}$ for an assumed flow-zone thickness of $1 \mathrm{~m}$. Injection Test 2 (injection rate of 6.0 $\mathrm{Ls}^{-1}$ ) yields the highest transmissivity estimate, suggesting that this parameter may be flow-rate dependent at high injection rates. Becker (1991) noted a similar relationship between injection rates and measured transmissivity during packer tests at ODP Hole 735B, and attributed the difference to increasing disturbance of the formation as injection rates increase. The recovery data from the constant-rate injection tests yield transmissivities 4.7 to 9.2 times higher than the average result of the slug tests (Table 1). This difference may reflect either greater formation disturbance during the injection tests or lower permeabilities in the vicinity of the borehole. Therefore, it is difficult to determine which transmissivity estimate (slug test or injection test) is more reliable.

\section{DISCUSSION}

The packer tests at Site 892 provide an opportunity to examine the flow properties of an open fracture network within an accretionary prism fault zone. Approximately 10 months after the packer tests (Fall 1993), a second set of hydrogeologic tests were conducted in Hole $892 \mathrm{~B}$ at near-hydrostatic pressures when fractures were presumably closed (Screaton et al., unpubl. data). Results of the packer tests yielded transmissivity estimates up to 3 orders of magnitude higher than those estimated from the fall, 1993 tests. The pressure response during the packer experiments, specifically the constant-rate injection tests, indicates that some of this transmissivity change occurred as a sudden increase as fractures opened.

Laboratory tests on fault-zone core samples from Site 892 (Brown, this volume) yield insight on the relationship between transmissivity and effective stress. Hydraulic conductivities of samples from $109.5 \mathrm{~m}$ in Hole 892D and from $116.5 \mathrm{~m}$ in Hole 892A varied by factors of 40 and 200 , respectively, as excess pressures varied from hydrostatic to $0.05 \mathrm{MPa}$ below lithostatic. However, it is difficult to directly correlate laboratory and in situ measurements. The estimated transmissivity of the lower section of Hole 892B measured during the packer tests ( 1 to $9.2 \times 10^{-5} \mathrm{~m}^{2} \mathrm{~s}^{-1}$ ) is at least 3 orders of magnitude higher than the highest transmissivities calculated from laboratory test results ( 1 to $1.6 \times 10^{-8} \mathrm{~m}^{2} \mathrm{~s}^{-1}$; Brown, this volume). The highest transmissivity values are estimated using the laboratory hydraulic conductivities measured at low effective stresses ( 0.05 MPa) and assuming a $24-\mathrm{m}$-thick fault zone. The difference between laboratory and in situ determinations may partly be due to scale, as larger fractures may exist in situ that are not present in the experimental samples. In addition, the transmissivities estimated from the packer test results reflect the permeability increase as the least principal stress is exceeded, and fractures open.

It appears that lithostatic fluid pressure is not necessary to dilate fractures within this thrust fault. The occurrence of open fractures at sub-lithostatic pressures requires that the dilatant fractures do not wholly support the overlying sediment column and therefore that the least principal stress is not vertical, as is generally assumed for a compressive environment. The instantaneous shut-in pressure $(0.315$ to $0.325 \mathrm{MPa}$ above hydrostatic) suggests that open fractures support about $50 \%$ of the overburden, and therefore dip $45^{\circ}$ or more. Fracture systems and stratal disruption observed in Hole 892A exhibit dip inclinations up to $63^{\circ}$ (Shipboard Scientific Party, 1994). As the fault dips about $14^{\circ}$, presumably some of the hydrofractures occur subparallel to the fault zone.

Background pore pressures determined from the packer tests are very close to that necessary to maintain open fractures within the fault zone. If these pressures are representative of in situ formation pressure, the fault zone may have been at or near sufficient pressures to maintain open fractures prior to disturbance by drilling operations. Development of high fracture transmissivities at elevated fluid pressures (low effective stresses) would contribute to the extensive expulsion history recorded by large volumes of diagenetic carbonate deposits and extensive relict clam communities observed at the fault trace (Carson et al., 1994; Moore, 1991).

\section{SUMMARY}

Results of shipboard hydrogeologic tests conducted during ODP Leg 146 provide the first field determination of transmissivity within a modern accretionary prism fault zone. Transmissivity estimates range from 1 to $9.2 \times 10^{-5} \mathrm{~m}^{2} \mathrm{~s}^{-1}$. Permeability is more difficult to constrain, because the thickness of the active flow zone is not known; reasonable assumptions yield permeability estimates ranging from $6.1 \times 10^{-14}$ to $1.4 \times 10^{-11} \mathrm{~m}^{2}$. The packer test results also yield information on the state of stress within the second ridge of the accretionary prism. Analysis of the constant-rate injection test recoveries indicates that fractures close at pore pressures 0.315 to $0.325 \mathrm{MPa}$ above hydrostatic. Background pressure in the vicinity of the borehole during the tests is approximately 0.25 to $0.30 \mathrm{MPa}$ above hydrostatic. This value may be an underestimate of formation pressures because the borehole had been open for 12 hours prior to the testing.

\section{ACKNOWLEDGMENTS}

The packer test measurements would not have been possible without the expertise and hard work of the $S E D C O / B P 471$ drill crew, especially the core technicians. Keir Becker provided training on use of the packer and advice on the testing and on data interpretation. This paper benefited from reviews by J. Tellam, G. Westbrook, and A. Fisher. This study was supported by a JOI/USSAC fellowship to Elizabeth Screaton and NSF grant OCE - 9202603. 


\section{REFERENCES}

Anderson, R.N., and Zoback, M.D., 1982. Permeability, underpressures, and convection in the oceanic crust near the Costa Rica Rift, eastern equatorial Pacific. J. Geophys, Res., 87:2860-2868.

Anderson, R.N., Zoback, M.D., Hickman, S.H., and Newmark, R.L., 1985. Permeability versus depth in the upper oceanic crust: in situ measurements in DSDP Hole 504B, eastern equatorial Pacific. J. Geophys. Res., 90:3659-3669.

Becker, K., 1988. A guide to ODP tools for downhole measurements. ODP Tech. Note, 10.

1989. Measurements of the permeability of the sheeted dikes in Hole 504B, ODP Leg 111. In Becker, K., Sakai, H., et al., Proc. ODP, Sci. Results, 111: College Station, TX (Ocean Drilling Program), 317-325.

1991. In-situ bulk permeability of oceanic gabbros in Hole 735B, ODP Leg 118. In Von Herzen, R.P., Robinson, P.T., et al., Proc. ODP, Sci. Results, 118: College Station, TX (Ocean Drilling Program), 333-347.

Bredehoeft, J.D., and Papadopulos, S.S., 1980. A method for determining the hydraulic properties of tight formations. Water Resour. Res., 16:223-238.

Carson, B., Seke, E., Paskevich, V., and Holmes, M.L., 1994. Fluid expulsion sites on the Cascadia Accretionary Prism: mapping diagenetic deposits with processed Gloria imagery. J. Geophys. Res., 99:11959-11969.

Cooper, H. H., Jr., Bredehoeft, J.D., and Papadopulos, I.S., 1967. Response of a finite diameter well to an instantaneous charge of water. Water Resour. Res., 3:263-269.

Cornet, F.H., and Valette, B., 1984. In situ stress determination from hydraulic injection test data. J. Geophys. Res., 89:11527-11537.

Davis, E.E., Becker, K., Pettigrew, T., Carson, B., and MacDonald, R., 1992. CORK: a hydrologic seal and downhole observatory for deep-ocean boreholes. In Davis, E.E., Mottl, M.J., Fisher, A.T., et al., Proc. ODP, Init. Repts., 139: College Station, TX (Ocean Drilling Program), 43-53.
Freeze, R.A., and Cherry, J.A., 1979. Groundwater: Englewood Cliffs, NJ (Prentice-Hall).

Hickman, S.H., Langseth, M.G., and Svitek, J.F., 1984. In situ permeability and pore-pressure measurements near the Mid-Atlantic Ridge, Deep Sea Drilling Project Hole 395A. In Hyndman, R.D., Salisbury, M.H., et al., Init. Repts. DSDP, 78B: Washington (U.S. Govt. Printing Office), 699-708.

Hickman, S.H., and Zoback, M.D., 1983. The interpretation of hydraulic fracturing pressure-time data for in-situ stress determination. Hydraulic Fracturing Stress Measurements: Washington (Natl. Acad. Press), 44-54.

Kennish, M.J., 1989. Practical Handbook of Marine Science: Boca Raton, FL (Chemical Rubber Publ. Co.).

Linke, P., Suess, E., Torres, M., Martens, V., Rugh, W.D., Ziebis, W., and Kulm, L.D., 1994. In situ measurement of fluid flow from cold seeps at active continental margins. Deep-Sea Res., 41:721-739.

Moore, J.C., 1991. Geophysicists meet bioherm: seep story surfaces. JOI/USSAC Newsl., 4:1-3.

Neuzil, C.E., 1982. On conducting the modified "slug" test in tight formations. Water Resour. Res., 18:439-441.

Papadopulos, S.S., Bredehoeft, J.D., and Cooper, H.H., 1973. On the analysis of "slug test" data. Water Resour. Res., 9:1087-1089.

Shipboard Scientific Party, 1994. Site 892. In Westbrook, G.K., Carson, B., Musgrave, R.J., et al., Proc. ODP, Init. Repts., 146 (Pt. 1): College Station, TX (Ocean Drilling Program), 301-378.

Theis, C.V., 1935. The relation between the lowering of the piezometric surface and the rate and duration of discharge of a well using groundwater storage. Trans., Am. Geophys. Union, 2:519-524.

Date of initial receipt: 2 September 1994

Date of acceptance: 24 March 1995

Ms 146SR-227 

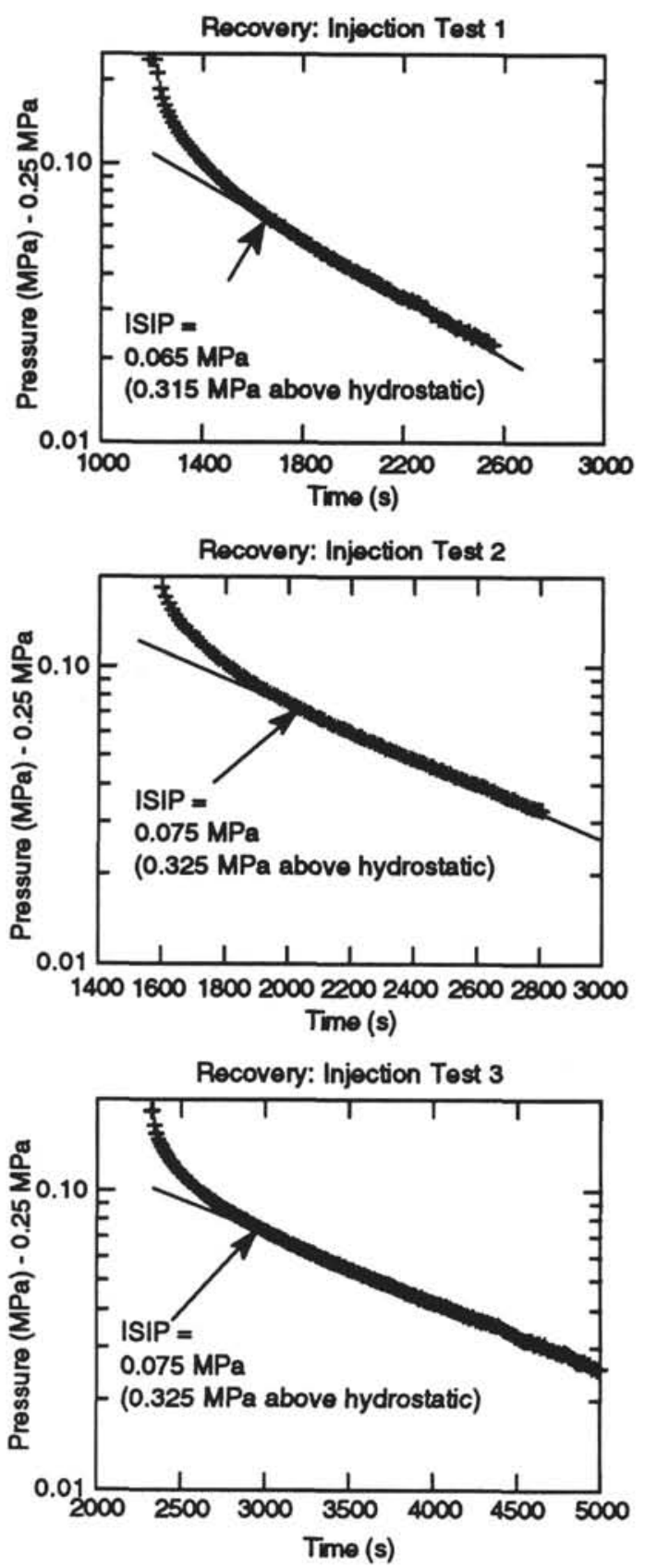

Figure 4. Data from injection tests for determination of formation pore pressure and instantaneous shut-in pressure (ISIP) following the method of Cornet and Valette (1984). The method is based on the observation that after the fracture is closed, pressures decay in an exponential manner to the formation pressure. The formation pore pressure is determined by finding the value for which $\log$ (pressure-formation pressure) is best represented by a straight line. The first pressure value that lies on this line is assumed to be the ISIP.
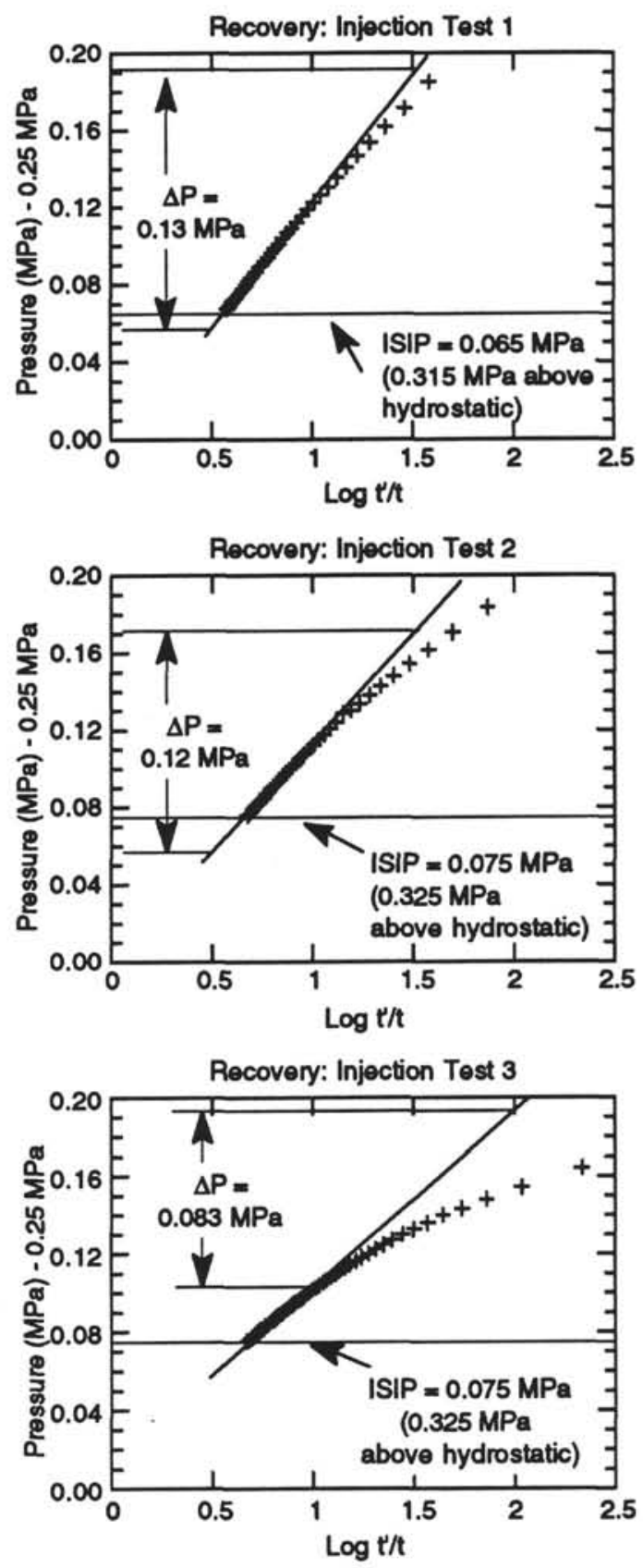

Figure 5. Data from injection test recoveries with linear regression lines. Only pressure values greater than the ISIP were used for the analyses. 